\title{
Phytochemical Characterization, Anti-inflammatory and Anti-ulcer Activity of a Spontaneous Succulent Delosperma Reseii
}

\author{
Abdelhak Rouibi*, Soraya Boukrita \\ Laboratory of Biotechnology, Environment and Heath Department of Population and Organisms Faculty of SNV, \\ University of Blida, Algeria
}

Copyright $\subset 2018$ by authors, all rights reserved. Authors agree that this article remains permanently open access under the terms of the Creative Commons Attribution License 4.0 International License

\begin{abstract}
In Algeria, the study of traditional medicine and treatment by plants is of particular interest. This country is known by, the diversity of its climate, the nature of its soil and the wealth of its medicinal flora. To value this floral heritage with medicinal and economic interest, our choice concerned to an underestimated plant in traditional medicine, it is about the magic carpet (Delosperma Resei). This plant belongs to the family Aizoaceae. The genus Delosperma includes about 150 species of shrub and perennial succulent, a persistent or semi persistent foliage, growing in hilly plains. The current work reveals through the phytochemical screening and the study of some pharmacological properties, anti-inflammatory and antiulcer activity, the therapeutic virtues of a spontaneous succulent Delosperma Reseii. The reactions of characterization were used to identify the chemical constituents of Delosperma Reseii leaves. The results of our study revealed the wealth of our plant in tannins and saponosides. Leuco-anthocyans and flavonoids exist in average levels. However, the extract of saponins showed an anti-inflammatory effect clearly lower than that generated by Diclofenac (the percentage of reduction is about $36.59 \%$ ). The anti-inflammatory activity of the saponins extract appeared less effective than that of Diclofenac. The study of the anti-ulcer activity showed that the extract of tannins at $10 \%$ in the experimental group induced a decrease in the index of ulceration up to $0 \%$. However, in the control group treated with Omeprazole, this index falls to $0 \%$. The tannins in the methanolic extract of the plant have shown an important anti-ulcer effect, but lower compared to Omeprazole.
\end{abstract}

Keywords Delosperma Reseii, Anti-inflammatory, Anti-ulcer, Saponins, Tannins

\section{Introduction}

Plants, vital elements of biological diversity are used principally for the wellness of human being (Adjanohoun and al, 1996). The relationship between the human and plant world have existed for long time (Baytop, 1999; Din and al, 2011). Outside the cultivated plants, several less known wild plants hold a big cultural importance and a strong economic potential for the food and the cares.

The medicinal plants constitute precious resources for most of rural population in Africa, where more than $80 \%$ of this population use it to insure health care (Dibong and al, 2011). In addition, these plants are valuable resources for the pharmaceutical industry (Awono et al, 2009). In Algeria, the study of traditional medicine and treatment by plants is of particular interest. This country is known by, the diversity of its climate, the nature of its soil and the wealth of its medicinal flora. To value this floral heritage with medicinal and economic interest, our choice concerned to an underestimated plant in traditional medicine, it is about the magic carpet (Delospermaresei). This plant belongs to the family Aizoaceae. The genus Delosperma includes about 150 species of shrub and perennial succulent, a persistent or semi persistent foliage, growing in hilly plains.

The current work reveals through the phytochemical screening and the study of some pharmacological properties, anti-inflammatory andantiulcer activity, the therapeutic virtues of a spontaneous succulent Delosperma reseii.

\section{Material and Methods}

\section{Plant Material}

The harvest of the plant was conducted on December 2011 in Sidi Fredj region (west of Algiers). After drying of 
leaves in an oven at $30^{\circ} \mathrm{C}$ during 20 days, a grinding was carried out and the powder is preserved in hermetically closed boxes.

\section{Animal Material}

Animals: mice and Wistar rats (150-200g) come from breedings of the Industrial Society of Pharmaceutical Products El Harrach Algiers.

\section{Preparation of the Infusion}

$20 \mathrm{~g}$ of powder are placed in $100 \mathrm{ml}$ of boiling water, we let infuse during 15 minutes, after filtration, the filtrate is adjusted to $100 \mathrm{ml}$ with the distilled water.

\section{Characterization of the Main Chemical Constituents of Extracts}

The reagents of classic characterization allowed highlighting the following chemical groups:

- Quinones were revelated by (hydrochloric acid + $0,1 \mathrm{~N}$ chloroform)

- Alkaloids were revelated by (reagent of Dragendorff and of Mayer),

- Glucosides revelated by $\left(\mathrm{H}_{2} \mathrm{SO}_{4}\right)$,

- Flavonoïds revelated by (cyanidin reaction),

- Saponins revelated by (foaming index),

- Tannins reveleted by (ferric chloride).

\section{Extraction of Tannins}

$15 \mathrm{~g}$ of leaves are placed in $40 \mathrm{ml}$ of a mixture of acetone water (7/3). After evaporation under reduced pressure, tannins of very high molecular weights were precipitated by addition of sodium chloride brine (at saturation). The least condensed products, are then extracted with ethyl acetate, and precipitated with chloroform (European Pharmacopoeia, 2001).

\section{Extraction of Saponins}

The extraction of saponins was carried out according to the following scheme: In a test tube, $3 \mathrm{~g}$ of leaf powder were introduced in $8 \mathrm{ml}$ of ethanol and $1 \mathrm{ml}$ water. the mixture was brought to a boil in the bain-marie at $65^{\circ} \mathrm{C}$ for $10 \mathrm{~min}$, the mixture was filtered under heat the alcoolat on filter paper wrinkled in a test tube of 16 . The residue of saponins is obtained (European Pharmacopoeia, 2001).

\section{Study of the Anti-inflammatory Activity of the Extract of Saponins}

Method of Winter (Winter and al, 1962):

This test allows to compare the reaction of the plantar edema after administration of equal doses of the anti-inflammatory test product (extract of saponins 10\%) and of the corresponding reference product (Diclofenac $75 \mathrm{mg})$.

The mice were divided into three groups of six mice each. A control group, a reference group and an experimental group:
At time $\mathrm{T}_{0}$ :

Mice of each group receive the following suspensions:

- Control group: each mouse received $0.5 \mathrm{ml}$ of distilled water.

- Reference group: each mouse received $0.5 \mathrm{ml}$ of diclofenac $75 \mathrm{mg}$.

- Experimental group: each mouse received $0.5 \mathrm{ml}$ of the extract of saponins $10 \%$.

At time $\mathrm{T}_{0}+30 \mathrm{~min}$

Mice were given injections of $0.025 \mathrm{ml}$ of $1 \%$-carragenine solution in saline solution $0.9 \%$ under the plantar fasciitis of the mouse left hind paw.

At time $\mathrm{T}_{0}+4 \mathrm{H}$ :

The animals were sacrificed by breaking the neck. The hind legs are cut up to the joint. The percentage of reduction of the edema in the treated mice compared with the references is calculated according to the following relations:

$\%$ of edema reduction $=\%$ of control edema $-\%$ of reference edema $* 100$

\section{Study of Theanti-ulcer Activity of the Extract of Tannins (Colot. M, 1972)}

The study of the anti-ulcer activity involved two steps:

Step 1: Ulcer test: three groups of rats (control, experimental, reference), each containing 6 animals, were submitted to 18 hours liquid diet. The ulcer is caused in the latter by a daily oral administration of phenylbutazone (200 $\mathrm{mg} / \mathrm{kg}$ ) for 4 consecutive days.

Step 2: Antiulcer test: Consists of taking an oral dose of the extract of tannins of the plant 10\% (experimental group) and of the reference product Omeprazole $20 \mathrm{mg}$ (reference group) during 14 consecutive days to the rats with gastric ulcer.

On day 14, rats were sacrificed, their stomachs were removed and a macroscopic study was performed to assess the number of ulcers according to the scoring of Lowff 1971, the ulcer index was calculated using the following formula (Lowff, 1977):

$\mathrm{UI}=$ summed score $\times \%$ stomach ulcer $\mid$ number of animals

\section{Results and Discussion}

\section{Results of Phytochemical Study}

The results of our study revealed the wealth of our plant in tannins and saponosides. Leuco-anthocyans and flavonoids exist in average levels; however alkaloids, anthocyans and the free quinones are weakly represented. Nearly all existing plant secondary metabolites are phenolic.

However, the high level of polyphenols found in this our plants provides several therapeutic properties; 
anti-carcinogenic and anti-ulcer activity of flavonoids and phenolic acids. (Ko and al, 2000; Liand al, 2008; Hirata and al, 2009).

The extracts and essential oils of many plants have been investigated for their antioxidant activity. (Amakura and al, 2002; Aruoma and al, 1998; Yehia and al, 2013).The polyphenolic compounds are secondary plant metabolites found in numerous plant species, these polyphenolic compounds have been reported to play key antioxidant roles. The phytochemicals especially the flavonoids have been extensively studied for their antioxidant activities using the mechanism of delocalization of the single electron of the radical. The plants studied in the present investigation demonstrated considerable free radical scavenging activity, which could be supplementary for the amelioration of inflammatory reactions.

\section{Results of the Anti-inflammatory Activity}

The percentage of reduction of edema of posterior left legs of mice pretreated by Diclofenac reached $50,89 \%$,however,in mice treated with the extract of saponins this percentage reached $36.59 \%$. The saponins extract of plant show an anti- inflammatory effect clearly lower than that generated by Diclofenac (the percentage of reduction is about $36.59 \%$ ).

The anti-inflammatory activity of the saponins extract appears less effective than that of Diclofenac. Indeed, the administration of saponins extract appears less effective compared to the administration of crude plant extract. In phytotherapy, the presence of several active molecules enhances the therapeutic effect of the plant (synergistic effect). Recent researches have shown that several secondary metabolites have anti-inflammatory properties, in particular saponins and flavonols. These compounds relieve muscle pain by accelerating tissue repair at molecular level. Some studies have highlighted that saponins and total oligomers flavonoic of the root bark of Zizyphus lotus at dose of $200 \mathrm{mg} / \mathrm{kg}$ show an important anti-inflammatory activity. This activity exceeds that of the reference product (Borgi and Chouchane, 2006).

The edema caused by carrageenan in mouse paw has three distinct phases:

A first phase which involves histamine and 5-hydroxytryptamine which promote vasodilatation, a second phase which uses kinins as mediators that increase vascular permeability and a third phase whose mediator is supposed to be prostaglandin associated with leukocyte migration into the inflamed area (Lindsey and al, 1999; Attal and Bouhassira, 2000). Prostaglandins are involved in acute and chronic inflammatory processes. Anti-inflammatory drugs are generally involved in opposing the effect of these chemical mediators: histamine, serotonin, kinins and prostaglandins. The anti-inflammatory properties of the aqueous extract of the plant can be justified by the presence of some of these water-soluble constituents. Secondary metabolites derived from this plant would find a therapeutic indication as analgesic and anti-inflammatory with a possible inhibitory action of prostaglandins partly responsible for pain.

Variety of phytochemicals like flavonoids, terpenoids, and saponins has been described to possess significant anti-inflammatory activity. Several studies proved naturally occurring coumarins (Yasser, and Nabil, 2012) and flavonoids (Selvum, 2004) act as dual inhibitors of cyclooxygenase and 5- lipoxygenase activities. Flavonoids inhibit biosynthesis of prostaglandins (the end products of the COX and lipoxygenase pathways), which acts as a secondary messengers and are involved in various immunologic responses. (Min and al, 2004). Inhibition of these enzymes provides the mechanism by which flavonoids inhibit inflammatory disorders (Ram and al, 2012).

\section{Result of the Anti-ulcer Activity}

Table 1. Ulcer index calculation

\begin{tabular}{|c|c|c|c|c|}
\hline & $\begin{array}{c}\text { Number } \\
\text { of rats }\end{array}$ & $\begin{array}{c}\text { \% of rats } \\
\text { with ulcers }\end{array}$ & $\begin{array}{c}\text { Summed } \\
\text { score }\end{array}$ & $\begin{array}{c}\text { Ulcer } \\
\text { index }\end{array}$ \\
\hline Control & 05 & $100 \%$ & 09 & $180 \%$ \\
\hline Experimental & 05 & $100 \%$ & 01 & $20 \%$ \\
\hline Reference & 05 & $100 \%$ & 00 & $00 \%$ \\
\hline
\end{tabular}

The results of the table 1show that ulcer index in control group reaches $180 \%$. This value means that all individuals have developed ulcers caused by phenylbutazone. After treatment of individuals of experimental group by tannins extract $10 \%$ we noticed that the value of ulcer index falls to $20 \%$. However, in the reference group treated by Omeprazole (antiulcer drug), the ulcer index reaches $0 \%$.

The tannins of the plant have shown an important anti-ulcer effect, but lower compared to Omprazole. The methanolic extracts of delosperma and especially tannins have a comparable anti-ulcer activity as that of Omeprazole. We compare our results with those obtained on other plants, it appears that our plant extract has a gastro protective effect similar to that obtained by the tannins from the trunk bark of Parkiabiglobosa (Chaibou, 1996), of Ajuga iwiet Teucruimpoluim (Habib, 1990) and of Acacia nilotica var. adansonii, (Kam, 1995).

The study of curative activity of gastric ulcer showed the efficiency of tannins extracts $10 \%$ of our plant in healing stomach ulcers. The once-daily administration of this extracts in $10 \%$ resulted in an almost complete cure $(80 \%)$ at the end of 14 days.

We do not know the mechanism by which this plant intervenes in gastric protection and gastric ulcer healing. The curative activity on gastric ulcers of tannin extract may possibly be linked either to an inhibition of gastric acid production or to an increase in mucus production or to a healing effect of the lesions. Tannins are probably involved by the latter mechanism. Tannins calm inflammation, exert astringent and protective action on the stomach mucosa and 
reduce excess acidity. Tannins are among phenols, which exhibit anti-inflammatory and antiseptic activity.

The preliminary phytochemical analysis of $D$. reseii extract showed the presence of polyphenols and tannins. The antioxidant components from many plant extracts have been extensively confirmed for their antiulcerogenic efficacy (Salvayre and al, 1982). It is suggested that these active compounds would be able to stimulate prostaglandin secretion and counteract the deteriorating effects of reactive oxydants in gastro-intestinal lumen. (Pandian and al, 2002; Asuzu and al, 1990). The antiulcer activity of $D$. reseii may be attributed to its polyphenolic constituents, particularly quercetin, reported from it. (Sari and al, 1990). In this study, we observed that the extract of D. reseii leaves provides significant antiulcer effect against gastric ulcers in rats, a fact that supports the traditional use of the decoction of $D$. reseii leaves for its antiulcer effect.

\section{Conclusions}

The results of the present study clearly indicated that aqueous extract of $D$. reseii leaf exhibited an anti-inflammatory and antiulcerogenic activity. The quantification of secondary metabolites shows that the total phenolics, and tannin content are higher.

The study concluded that the plant substances such as total phenols, tannins and saponosides, posse an appreciable anti-inflammatory and antiulcer activities. The importance of this plant will help to reveal its potential to give phytotherapeuticals for human health. Further, detailed investigation, chemical studies, and screening for medicinal properties will provide cost effective and reliable source of medicine for the welfare of humanity.

\section{REFERENCES}

[1] Adjanohoun E., Aboubakar N., Dramane K., Ebot M.E., Ekpere J.A., Enow-Orock E.G., Focho D., Gbile Z.O., Kamanyi A., KamsuKom J., Keita A., Mbenkum T., Mbi C.N., Mbiele A.L., Mbome I.L., Mubiru N.K., Nancy W.L., Nkongmeneck B., Satabie B., Sofowora A., Tamze V., Wirmum C.K. (1996). Contribution to ethnobotanical and floristical studies in Cameroon. OAU / STRC.

[2] Amakura Y., Umino Tsuji.S. (2002). Constituents and their antioxidative effects in eucalyptus leaf extract used as a natural food additive. Food Chem., 77, pp 47-56.

[3] Asuzu IU, Onu O.U. (1990). Antiulcer activity of the ethanolic extract of Combretum dolichopetalum root. Int. J. Crude Drug Res., 28, pp 27-32.

[4] Aruoma O.I. Free radicals, oxidative stress, and antioxidants in human health and disease. J. Ame. Oil Chem. Soc., 75, pp 199-212.

[5] Attal N, Bouhassira D. (2000). New approaches to pain.
Pharmaceutical French Annales, Vol. 58, pp 121-134.

[6] Awono A., Manirakiza D., Ingram V. (2009). Mobilization and capacity building Small and medium-sized companies involved in the sector of non-timber forest products in Central Africa. CIFOR Cameroon. http, pp cameroun foret. com / en / library / 10666.

[7] Baytop T. (1999). Therapy with plants in Turkey, past and present, second ed. Nobel Tip Kitapevi, Istanbul (in Turkish).

[8] Borgi W., Ghedira K., Chouchane N. (2007). Antiinflammatory and analgesic activities of Zizyphus lotus root barks. Fitoterapia, 78, pp. 16-19. doi: 10.1016/j.fitote. 2006.09.010.

[9] Chaibou Mohamadou (1996). Study of anti-ulcer activity of the extracts of the stem bark of Parkia biglobosa. Thesis of Doctor of Veterinary Medicine Faculty of Medicine and Pharmacy of Dakar.

[10] Colot M. (1972). Notion technique de pharmacologie générale édition Masson.

[11] Dibong S.D., Mpondo Mpondo E., Ngoye A., Kwin N.F., Betti J.L. (2011a). Ethnobotany and phytomedicine of medicinal plants sold in the markets of Douala, Cameroon. Journal of Applied Biosciences, 37, pp 2496-2407.

[12] Din N., Mpondo Mpondo E., Dibong S.D., Kwin N.F., Ngoye A. (2011). Inventory and identification of plants used in the treatment of diabetes in Douala town Cameroon). European Journal of Medicinal Plants, 1(3), pp 60-73.

[13] Habib J., Ben Douissa F., Chedira K. (1990). Contribution to the study of traditional medicine in Tunisia: anti-ulcer activity of Ajuga iva, Rhusoxy canthera and Teucrium polium (387-388) note 1 Ethnopharmocology Metz European Symposium 22-25.

[14] Hirata T., Fujii M., Akita K., Yanaka N., Ogawa K., Kuroyanagi M., Hongo D. (2009). Identification and physiological evaluation of the components from Citrus fruits as potential drugs for anti-corpulence and anticancer Bioorganic \& Medicinal Chemistry, 17, pp 25-28.

[15] Kam A. (1995). Contribution to the study of anti-ulcer activity of total extracts of Acacia nilotica (L.) fruit walls. Thesis of Doctor of Veterinary Medicine Faculty of Medicine and Pharmacy of Dakar.

[16] Ko W. G., Kang T. H., Lee S. J., Kim N. Y., Kim Y. C., Sohn D. H., Lee B. H. (2000). Polymethoxy flavonoids from Vitexrotun difolia inhibit proliferation by inducing apoptosis in human myeloid leukemia cells; Food and Chemical Toxicology, 38, pp 861-865.

[17] Li H.B., Wong C.C., Cheng K.W., Chen F. (2008). Antioxidant properties in vitro and total phenolic content in methanol extracts from medicinal plants. L.W.T., 41, pp 385-390.

[18] Lindsey Jager A. K., Raidoo D. M., Van Staden J. (1999). Screening of plants used by South African traditional healers in the treatment of dysmenorrhoea for prostaglandin syhthesis inhibitors and uterine relaxing activity. Journal of Ethnopharmacology, Vol. 64(1), pp 9-14.

[19] Lowoff J. M. (1977). Ulcerogenic activity in rats. Data Sheet $\mathrm{N}^{\mathrm{o}}$. 12 Jou. Pharmacology, 2(1), pp 81-83. 
[20] Min H.P., Ching S.L., Chi T.H. (2010) Anti-inflammatory activity of natural dietary flavonoids. Food Funct., 1, pp 1531

[21] Pandian R.S., Anuradha C.V., Viswanathan P. (2002). Gastroprotective effect of fenugreek seeds (Trigonella foenum graecum) on experimental gastric ulcer in rats. $\mathbf{J}$ Ethnopharmacol, 8, pp 393-7.

[22] Salvayre R., Braquet P., Perochot L., Douste-Blazy L. (1982). Comparison of the scavenger effect of bilberry anthocyanosides with various flavonoids. Flavonoids Bioflavonoids, 11, pp 437-42.

[23] Sari H., Sirpa O.K., Marina I.H., Hannu M.M., Riitta A.T. (1999). Content of the flavanols quercetin, myricetin and kaemferol in 25 edible berries. J. Agri. Food Chem., 47, pp 2274.

[24] Selvum C., Jachak S.M., Bhutani K.K. (2004). Cyclooxygenase inhibitory flavonoids from the Stem Bark of Semecarpus anacardium Linn. Phytoth. Res., 18, pp
$582-584$

[25] Ram H.N., Sriwastava N.K., Makhija I.K., Shreedhara C.S. (2012). Anti-inflammatory activity of Ajmodadi Churna extract against acute inflammation in rats. J. Ayurveda Integr. Med., 3, pp 33-37.

[26] Winter C.A., Risley E.A., Nuss W. (1962). Carrageenan induced edema in hind paw of rats as an assay for anti-inflammatory drugs. Proc Soc. Exp. Biol. Med., 11, pp 544-547.

[27] Yasser A.S., Nabil H.O. (2012). Anti-inflammatory new coumarin from the Ammi majus L. Org. Med. Chem. Lett., 2, pp 1-4.

[28] Yehia A.T.A., Alzowahi F.A.M., Kadam T.A., Shaikh R.U. (2013). In vitro evaluation of antimicrobial and antioxidant activity of Dragon's blood tree (Dracaena cinnabari Balf.f.) of Socotra Island (Yemen). J. Coast. Life Med., 1, pp 111117. 